\title{
Korea, Democratic People's Republic of
}

National Cancer Institute

\section{Source}

National Cancer Institute. Korea, Democratic People's Republic of. NCI Thesaurus. Code C16773.

A country in eastern Asia, occupying the northern half of the Korean Peninsula, bordering the Korea Bay and the Sea of Japan, between China and South Korea. 